\title{
Gender Variation in Knowledge Level on Precautionary Measures against Pesticides' Health and Environmental Hazards among Cocoa Farmers in Nigeria
}

\author{
Olowoyo Olamide Ahmed \\ Department of Agricultural Extension and Rural Development, Obafemi Awolowo University, Ile Ife, Nigeria
}

Email address:

meedey4real@yahoo.com

\section{To cite this article:}

Olowoyo Olamide Ahmed. Gender Variation in Knowledge Level on Precautionary Measures against Pesticides' Health and Environmental Hazards among Cocoa Farmers in Nigeria. International Journal of Applied Agricultural Sciences. Vol. 3, No. 6, 2017 , pp. 166-173. doi: 10.11648/j.ijaas.20170306.15

Received: November 6, 2017; Accepted: November 20, 2017; Published: December 26, 2017

\begin{abstract}
The study was conducted in Ekiti State, Nigeria due to its predominance in cocoa production. It examined the variation in knowledge level on precautionary measures against pesticides health and environmental hazards among male and female cocoa farmers. 120 male and 120 female cocoa farmers were selected through multi stage purposive sampling technique from five Local Government Areas with predominance in cocoa production in the state. Data collected from the survey were analyzed with descriptive and inferential statistics. The findings indicated that male as well as female cocoa farmers in the study area had moderate level of knowledge to prevent them from the incidence of health and environmental hazards of pesticide usage, though male cocoa farmers had a better level of knowledge compare to their female counterparts. Majority (69.2 per cent Male Cocoa Farmers and 57.5 per cent Female Cocoa Farmers) had moderate level of knowledge. The overall result shows that majority 63.3 per cent of cocoa farmers had moderate knowledge in precautionary measures. This study also find out that despite that male and female cocoa farmers are knowledgeable about the precautionary measures of health and environmental hazards they seldom practice it, which in turn contributes to the incidence of the hazards. It was recommended that there should be continuous and regular training for male and female cocoa farmers as regards precautionary measures to be taken on pesticides usage to increase their knowledge base on pesticides hazards.
\end{abstract}

Keywords: Gender Variation, Pesticide Hazards, Knowledge, Cocoa Production

\section{Introduction}

Gender is a term that is defined by the culture of the society hence varies from one society to the other and from time to time [1]. The word gender means more than being a male or a female. It is a culturally ascribed role, responsibility, privilege, opportunities, as well as constraints to either of the sexes. Gender has often been misunderstood as being about the promotion of women only, but gender focuses on the relationship between men and women, their roles, access to and control over resources, division of labor and needs [2] In this same perspective this study critically examined the variation in knowledge level on precautionary measures against pesticides health and environmental hazards among male and female cocoa farmers in the study area. Gender analysis entails having knowledge of both male and female roles and responsibilities, as it is the comparative analysis between these that will highlight the gender inequalities of any society. The inequalities here doesn't implies that female are worse off than male or vice versa; rather it brings about smooth identification of gender gaps and opportunity in achieving gender equity. The study of gender roles, opportunities, responsibility e. t. c has recently become urgent and a global trend in agricultural research, thereby researchers are making concerted efforts in identifying gender gaps. Recent research [3] posited that the socio-economic indicators of Nigerian data show that women forms 39 per cent of the total labor force, despite that they account for 49 per cent of the population. Majority of women in the labour force are found in the agricultural and informal sector of the national economy. Women role like men role is of great importance in agricultural production as they are 
responsible for carrying out 70 per cent of agricultural labour, 50 per cent of animal husbandry related activities and 60 per cent of food processing activities [4] The involvement of male and female farmers in cocoa production in Nigeria in term of production and productivity and in the use of agricultural input such as pesticides and labour input was also pointed out by [3]

Cocoa (Thoebroma cacao) has been a major tree crop and the first economic tree crop in Nigeria for a long time. Cocoa has contributed significantly to Nigeria economy, serving as a source of foreign exchange earnings, offered employments both to farmers and traders. Cocoa is a vital export crop for many countries, particularly in West Africa. It is also a major foreign exchange earner for some Central and South American countries and, to a lesser extent, for South and Southeast Asia. Cocoa production contributed over 80 per cent of the Gross National Product (GNP) of the Nigerian economy and its export accounted mainly for the agricultural export before independence in 1960 [5] Even though the growth in the petroleum industry has made its relative importance as a major exchange earner to decline over time. Despite this cocoa remain the largest single foreign exchange earner of all agricultural export crops and the backbone of the economy of the Southern States of Nigeria. Nigeria was the second leading world producer of cocoa in the 60s and early 70s [6]. But presently Nigeria is the fourth largest producer of cocoa in the world with annual production of 270,000 in 2012/13 according to Cocoa Association of Nigeria CAN [7]

The decline in cocoa production in Nigeria can be attributed largely to pests and diseases among other factors. Studies by ([8], [9]] shows that about 25-30 per cent loss in yield of cocoa has been attribute to the cocoa mirid, Sahlbergella singularis, about 17 per cent is lost through the feeding of the cocoa pod borer Characoma strictigrapta. More so, losses attributed to black pod disease caused by Phytophtora megakarya range from 30-90 per cent ([8],[9]) Research efforts have been made to develop various control techniques (cultural, biological and chemical), production of new seed variety which could be harnessed for integrated pest management of the important pests and diseases of cocoa in Nigeria. However, these technologies has not reach cocoa farmers effectively to enable them understand and adopt these ecological approaches therefore majority of the farmers still use pesticides among various methods available in reducing the incidence of cocoa pest and diseases such as shade management, planting resistance varieties and biological control. ([10], [11]) identified the indiscriminate use of these chemicals among smallholder cocoa farmers as a major problem. This indiscriminate use poses threat to farmers' health as well as the environment. Siddaramaiah and Srinivas (2010) [12] also elucidate that commercial agriculture is characterized by indiscriminate use of high doses of agrochemicals for quick and immediate return in investment which consequently leads to environmental hazards.

However, despite the contribution of pesticides to agricultural production, evidences in the last few decades have shown that they could also be detrimental to human health and the ecosystem [13]. Most cocoa farmers in Nigeria are ignorant of the hazardous effects of pesticides and rarely use protective kits, especially in cases where they are scarce. Majority of male and female cocoa farmers in Nigeria seldom observes other precautionary measures as they are fond eating, smoking or drinking in-between spraying activities. The left over pesticides and empty containers are not properly disposed as the containers are sometimes washed and used for domestic purposes. [13] Deviation from these precautionary measures exposes most cocoa farmers to the hazardous effects of pesticides. Many at times the farmers also damage the nozzles of their spraying equipment by enlarging the hole to increase the discharge rate. The lack of maintenance of pesticide application equipment is as a result of lack of spare parts which is due to unavailability/unaffordability of the spare parts and specialized mechanics to repair and maintain the equipment $[15,16]$ Studies have been carried out on the knowledge of farmers on environmental hazards of cocoa production [6] on farmers' knowledge level of precautionary measures in agro-chemicals usage on cocoa production [17] problems of pesticide usage among cocoa farmers in Nigeria [10] and operational habits and health hazards associated with pesticide usage by cocoa farmers in Nigeria [14] But the gender perspective of the perceived concerns of knowledge level on the precautionary measures of the health and environmental hazards of pesticide usage among cocoa farmers in Ekiti State has not been popularly investigated. Hence, it became imperative to identify the precautionary measures of pesticides hazards and determine the variation in knowledge of precautionary measures among male and female cocoa farmers in Ekiti State, Nigeria. Thus study reported the various precautionary measures available to male and female cocoa farmers, gender variation in knowledge level on precautionary measures of pesticide hazards and their personal and socioeconomic characteristics. In line with above objectives the hypothesis below was tested. There is no significant difference between male and female cocoa farmer's knowledge on precautionary measure of pesticide usage.

\section{Methodology}

The study was conducted in Ekiti State, Nigeria. The State was created in October $1^{\text {st }}, 1996$. It is called the fountain of knowledge and land of honour. Ekiti State fall within Latitude: $7^{\circ} 43^{\prime} 01^{\prime \prime} \mathrm{N}$ Longitude: 5²0'02" E. The state lie within the tropics bounded in the North by Kwara State, in the South by Ondo State, in the East by Kogi State and in the West by Osun state. The 2006 national population census puts the population of the area to be $2,384,212$ people. It has an approximate land area of 10,898.68 square kilometres [18] Ekiti State is known for cocoa production and income generated from cocoa production has been used in some developmental projects in the State. Cocoa production in Ekiti State is practiced by male and female farmers. The major language of the inhabitants is Yoruba and the dialect 
spoken is Ekiti, which has slight variations among the different communities. The major occupation of the inhabitants of the rural areas is farming. Multistage purposive sampling techniques were used to select respondents for the study. At the first stage, five Local Government Areas (LGAs) with high cocoa production were purposively selected for the study namely Ado Ekiti, Ekiti South West, Gbonyin, Ijero and Ise-Orun. At the second stage three communities with the high cocoa production were purposively selected from each LGAs to make a total of fifteen communities. At the third stage eight male and eight female cocoa farmers were selected from each of the communities through accidental sampling technique to make a total of 240 respondents for the study. Structured interview schedule was used to collect quantitative data from the respondents. Data collected were analyzed using both descriptive statistics (frequency counts, percentages, mean and standard deviation) and inferential statistical tools (ANOVA and Pearson correlation). Focus group discussion was used to collect qualitative data. Six focus group discussion sessions were conducted for the study, three sessions each for male and three sessions each for female cocoa farmers. Each FGD session comprised of 8-10 participants. The information elicited from the discussions was analyzed using content analysis method and was used to buttress quantitative findings.

\section{Result and Discussion}

\subsection{Socio-economic Characteristics}

Results in table 1 show the disaggregated ages of male and female cocoa farmers. Majority of male cocoa farmers (MCF) 79.2 per cent and female cocoa farmers (FCF) 90.8 per cent were aged between 30 and 60 years old. The mean age of MCF was $52.45 \pm 9.82$ while the mean age of FCF was $45.22 \pm 8.49$. The overall result show that majority 85 per cent of male and female cocoa farmers were aged between 30 and 60 years old. The overall mean was $48.8 \pm 9.84$. This finding is in tandem with [17] who found out that the mean age cocoa farmers in Edo and Osun State, Nigeria was 47.0. The findings also shows that higher percentage of FCF are in their active ages compare to their male counterpart, thus bringing improvement FCF involvement in cocoa production. This is buttressed by the work of [19] that cocoa female farmers in Ekiti State were in their economically active age.

Table 1. Distribution of respondents on personal and socio economics characteristics

\begin{tabular}{|c|c|c|c|c|c|c|}
\hline \multirow{2}{*}{ Variables } & \multicolumn{2}{|c|}{ Male (n=120) } & \multicolumn{2}{|c|}{ Female $(n=120)$} & \multicolumn{2}{|c|}{ Total $(n=240)$} \\
\hline & Freq & $\%$ & Freq & $\%$ & Freq & $\%$ \\
\hline \multicolumn{7}{|l|}{ Age } \\
\hline$\leq 30$ & 1 & 0.8 & 5 & 4.2 & 6 & 2.5 \\
\hline $30-60$ & 95 & 79.2 & 109 & 90.8 & 204 & 85 \\
\hline$>60$ & 24 & 20 & 6 & 5 & 30 & 12.5 \\
\hline Mean & 52.5 & & 45.2 & & 48.8 & \\
\hline SD & 9.82 & & 8.49 & & 9.84 & \\
\hline \multicolumn{7}{|l|}{ Household Size } \\
\hline$\leq 5$ & 26 & 21.7 & 45 & 37.6 & 71 & 29.6 \\
\hline $6-10$ & 81 & 67.5 & 70 & 58.3 & 151 & 62.9 \\
\hline$>10$ & 13 & 10.8 & 5 & 4.1 & 18 & 7.5 \\
\hline Mean & 7.36 & & 6.34 & & 6.82 & \\
\hline $\mathrm{SD}$ & 2.26 & & 1.97 & & 2.22 & \\
\hline \multicolumn{7}{|c|}{ Years of Formal Education } \\
\hline Not applicable & 64 & 53.3 & 38 & 31.7 & 102 & 42.5 \\
\hline$<6$ & 2 & 1.7 & 30 & 25.0 & 32 & 13.3 \\
\hline $6-12$ & 41 & 34.2 & 48 & 40.0 & 89 & 37.1 \\
\hline 13 and above & 13 & 10.8 & 4 & 3.3 & 17 & 7.1 \\
\hline Mean & 4.82 & & 4.92 & & 4.87 & \\
\hline SD & 5.71 & & 4.62 & & 5.18 & \\
\hline \multicolumn{7}{|c|}{ Contact with Ext Agents } \\
\hline No contact & 18 & 15.0 & 37 & 30.8 & 55 & 22.9 \\
\hline$\leq 5$ & 22 & 18.3 & 33 & 27.5 & 55 & 22.9 \\
\hline $6-10$ & 31 & 25.8 & 22 & 18.3 & 53 & 22.1 \\
\hline 11 and above & 49 & 40.8 & 28 & 23.3 & 77 & 32.1 \\
\hline Mean & 8.4 & & 5.5 & & 6.95 & \\
\hline SD & 5.37 & & 5.66 & & 5.52 & \\
\hline Primary Occupation & 110 & 91.7 & 82 & 68.3 & 192 & 80 \\
\hline Farming & 3 & 2.5 & 31 & 25.8 & 34 & 14.2 \\
\hline Trading & 5 & 4.2 & 3 & 2.5 & 8 & 3.3 \\
\hline Artisan & 2 & 1.7 & 4 & 3.3 & 6 & 2.5 \\
\hline \multicolumn{7}{|l|}{ Civil Servant } \\
\hline Annual Income from & & & & & & \\
\hline
\end{tabular}




\begin{tabular}{|c|c|c|c|c|c|c|}
\hline \multirow{2}{*}{ Variables } & \multicolumn{2}{|c|}{ Male $(n=120)$} & \multicolumn{2}{|c|}{ Female $(n=120)$} & \multicolumn{2}{|c|}{ Total $(n=240)$} \\
\hline & Freq & $\%$ & Freq & $\%$ & Freq & $\%$ \\
\hline$\leq \mathbb{N} 150,000$ & 41 & 34.2 & 53 & 44.2 & 94 & 39.2 \\
\hline 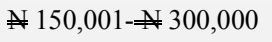 & 31 & 25.8 & 38 & 31.7 & 69 & 28.7 \\
\hline 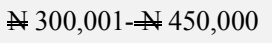 & 13 & 10.8 & 7 & 5.8 & 20 & 8.3 \\
\hline N 450,001 and above & 35 & 29.2 & 22 & 18.3 & 57 & 23.8 \\
\hline Mean & \multicolumn{2}{|c|}{ 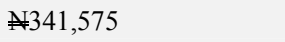 } & \multicolumn{2}{|c|}{ N259,291.6 } & \multicolumn{2}{|c|}{$\mathrm{N} 300,433.3$} \\
\hline SD & \multicolumn{2}{|c|}{$238,139.1$} & \multicolumn{2}{|c|}{$231,036.5$} & \multicolumn{2}{|c|}{$469,175.6$} \\
\hline \multicolumn{7}{|c|}{ Cocoa Farming Experience } \\
\hline$\leq 15$ & 16 & 13.3 & 38 & 31.7 & 54 & 22.5 \\
\hline $16-30$ & 61 & 50.8 & 64 & 53.3 & 125 & 52.1 \\
\hline 30 and above & 43 & 35.9 & 18 & 15.0 & 61 & 25.4 \\
\hline Mean & 27.9 & & 22.3 & & 25.1 & \\
\hline SD & 9.23 & & 9.68 & & 9.45 & \\
\hline
\end{tabular}

Source; Field Survey, 2015

Majority 67.5 per cent and 58.3 per cent of the male and female CFs respectively had 6-10 members of household. The mean household size among the MCF was $7.36 \pm 2.26$ members, while the mean was $6.3 \pm 1.96$ for FCF. The overall finding shows that majority 62.9 per cent of cocoa farmers had 6-10 members of household. The mean household size among cocoa farmers was $6.82 \pm 2.22$. The finding agrees with the report of [20] who estimated the average household size in rural areas of Nigeria as 6 . About $34 \%$ and $40 \%$ of male and female CFs respectively had between 6-12 years of formal education. The average years of formal education had by male and female CFs was $4.82 \pm 5.71$ and $4.91 \pm 4.62$ respectively The overall finding shows that 37.1 per cent of cocoa farmers in Ekiti State had between 6-12 years of formal education. The mean year of formal education for cocoa farmers was $4.87 \pm 5.18$. The findings revealed that female farmers in the study area spent more years in formal education than male farmers. This implies that female cocoa farmers have a better opportunity to acquire knowledge in cocoa production through formal education as compare to their male counterpart. About 41 per cent and 23 per cent of male and female CFs had contact with extension agents 11 times and above in the last 12 months respectively as compare to 26 times they are supposed to be visited in a year. The mean number of contacts was $8.36 \pm 5.37$ and $5.58 \pm 5.66$ The overall result shows that 32.1 per cent had contact of 11 and above times with extension agents in the last 12 months. The mean number of contact is $6.95 \pm 5.52$. The finding reveals that male CFs had more contact than their female counterpart in the study area. This might a significant implication on the knowledge level of male cocoa farmers as compare to their female counterpart. The implications for extension service in Ekiti State and other state in Nigeria revolve round the move to increase the number of contacts with cocoa farmers as well as encouragement for farmers out of farmers' business school. Majority 91.7 per cent MCF indicated farming as their primary occupation, while 68.3 per cent of the FCF indicated farming as their primary occupation. The overall finding shows that majority 80 per cent of cocoa farmers indicated farming as their primary occupation. This finding agrees with [21] that majority of rural dweller engaged in farming as their primary occupation and also with [22] that majority of Ekiti State cocoa farmers engaged in farming as their primary occupation. The mean annual income from cocoa production of male and female CFs were $\$ 341,575 \pm 231,036.48$ and $\$ 259,291 \pm 238,139.06$. The overall mean annual income of cocoa farmers was $\$ 300,433 \pm 469,175$. About 51 per cent MCF and 53 per cent FCF had cocoa farming experience between 16-30 years, while 35.9 per cent MCF and 15 per cent FCF had experience of 30 years and above. The mean cocoa farming experience in years of male and female CFs were 27.9 \pm 9.23 and $22.28 \pm 9.68$ years respectively. The findings revealed that male had relatively higher farming experience than their female counterparts, which implies that male CFs will have better knowledge on cocoa production and precautionary measures of pesticide usage compare to their female counterpart. The finding is in agreement with [6] who reported that the mean years of the cocoa farming experience among cocoa farmers in Nigeria, as 24 years.

\subsection{Knowledge on Precautionary Measures against Pesticides Health and Environmental Hazards}

\section{Rank-Order of Statements on Knowledge of Precautionary} Measure.

To assess cocoa farmers' knowledge on precautionary measures of health and environmental hazards of pesticides usage, a list of 20 statements were presented to the cocoa farmers based on a five point likert type scale of $1=$ Definitely false, $2=$ Somewhat Untrue, $3=$ Not Sure, $4=$ Somewhat true, $5=$ Definitely true. Results in Table 2 showed the mean scores for the respondent knowledge on precautionary measures. Male and female cocoa farmers had high knowledge in wearing of protective clothing that have a mean score of 4.58 and 4.17 with standard deviation of 4.27 and 1.19 for male and female CFs respectively. Farmers affirmed to this finding through FGD that 'When it comes to preventing oneself from hazards we know about wearing protective clothing and do wear them but not at all times' Excerpt from FGD. 
Table 2. Mean scores of respondents'knowledge on precautionary measures against pesticides hazards.

\begin{tabular}{|c|c|c|c|c|}
\hline Knowledge Statement & Male & $\mathbf{n}=\mathbf{1 2 0}$ & Female & $\mathbf{n}=\mathbf{1 2 0}$ \\
\hline & Mean & SD & Mean & SD \\
\hline Wearing of protective clothes and gloves can prevent me from pesticides hazards (WPCG) & 4.58 & 4.27 & 4.17 & 1.19 \\
\hline Not eating, drinking and smoking during the application of pesticides prevents hazards (NEDS) & 4.27 & 0.82 & 3.90 & 1.04 \\
\hline Reading and following label instructions before pesticides usage can combats hazards (RFLI) & 4.22 & 0.79 & 3.92 & 0.88 \\
\hline Using leftover pesticide solution in the same day reduces unnecessary contact with pesticides (ULPS) & 3.53 & 1.33 & 3.31 & 1.32 \\
\hline $\begin{array}{l}\text { Not keeping the leftover pesticide in drinking container is a good measure to reduce the incidence of } \\
\text { pesticide hazards (NKLP) }\end{array}$ & 4.05 & 0.89 & 3.92 & 1.02 \\
\hline Washing contaminated clothes separately prevents hazards (WCCS) & 4.30 & 0.81 & 3.85 & 1.09 \\
\hline Wearing of jungle boots during pesticide application prevents pesticides hazards (WJB) & 3.90 & 1.10 & 3.78 & 0.98 \\
\hline Using respirator during spraying helps to reduce inhalation of pesticide (URS) & 4.00 & 1.21 & 3.30 & 1.22 \\
\hline $\begin{array}{l}\text { Washing and cleaning spraying equipment after spraying chemicals helps to minimize unnecessary } \\
\text { contact with pesticide (WSES) }\end{array}$ & 4.21 & 0.93 & 4.30 & 1.00 \\
\hline $\begin{array}{l}\text { Bathing immediately after spraying of chemical eliminates all forms of pesticide contamination in the } \\
\text { body. (BASC) }\end{array}$ & 4.45 & 0.76 & 3.95 & 0.92 \\
\hline $\begin{array}{l}\text { Not entering the farm within } 24 \text { hours after spraying chemical help prevent direct contact with pesticide } \\
\text { (NEFS) }\end{array}$ & 3.66 & 1.14 & 3.43 & 1.31 \\
\hline Destroying contaminated food after spraying so as not to eat contaminated food (DCFS) & 4.29 & 1.03 & 3.40 & 1.39 \\
\hline $\begin{array}{l}\text { Burying or burning of empty chemical containers after spraying reduces it damage to the environment } \\
\text { (BECS) }\end{array}$ & 4.15 & 1.21 & 3.35 & 1.27 \\
\hline Adherence to recommended agronomic practices makes environmental hazards evitable (ARAP) & 3.36 & 1.14 & 3.50 & 0.95 \\
\hline Hygiene practices on the farm make farmers less vulnerable to hazards (HPF) & 3.92 & 0.98 & 3.58 & 0.94 \\
\hline Practicing of IPM techniques reduces environmental hazards (IPM) & 3.70 & 1.00 & 3.62 & 1.03 \\
\hline Use of diseases resistant varieties reduces the usage of pesticide (UDRV) & 4.03 & 1.00 & 3.71 & 0.98 \\
\hline Regular medical check-ups can reduce vulnerability to hazards (RMC) & 3.54 & 1.13 & 3.68 & 1.06 \\
\hline Grand Mean & 4.02 & & 3.69 & \\
\hline
\end{tabular}

Source: Field survey, 2015.

$\mathrm{SD}=$ Standard Deviation. Rating scale: $1=$ Definitely false, $2=$ Somewhat Untrue, $3=$ Not Sure, $4=$ Somewhat true, $5=$ Definitely true

Male cocoa farmers also had high knowledge on not eating and drinking during spraying $(X=4.27 \sigma=0.82)$, bathing immediately after spraying pesticides $(X=4.45 \sigma=0.76)$, reading and following label instructions $(X=4.22 \sigma=0.79)$, destroying contaminated foods $(\mathrm{X}=4.29 \sigma=1.03)$ washing hand after spraying pesticides ( $\mathrm{X}=4.25 \sigma=1.04)$. Conversely male cocoa farmers had moderate/fair knowledge on wearing jungle boot $(\mathrm{X}=3.90 \sigma=1.10)$, hygiene practices on farm $(\mathrm{X}=3.92 \sigma=0.98)$, practicing IPM techniques $(\mathrm{X}=3.70 \sigma=1.00)$.

However female cocoa farmers had high knowledge on washing and cleaning of spraying equipment after spraying $(\mathrm{X}=4.30 \sigma=1.00)$, batting immediately after spraying pesticides $(\mathrm{X}=3.95 \sigma=0.92)$, while they had moderate/ fair knowledge on not eating, drinking during spraying $(\mathrm{X}=3.90$ $\sigma=1.04)$, wearing jungle boots $(\mathrm{X}=3.78 \sigma=0.98)$, hygiene practice on farm $(\mathrm{X}=3.58 \sigma=0.94)$. Excerpts from FGD reveal that farmers are knowledgeable of wearing overall during pesticide spraying 'We have knowledge of wearing overall for chemical spraying but we seldom use it during spraying'. 'We are also knowledgeable on wearing jungle boots and hand gloves but we seldom use them whenever we want to spray pesticide because it cause a lot of heat during

\section{spraying'. Excerpt from FGD}

The grand mean score was 4.02 and 3.69 with standard deviation 0.32 and 0.28 for male and female $\mathrm{CFs}$ respectively. About $(60 \%$ and $55 \%)$ of the mean score of male and female CFs respectively were equal or greater than the grand mean while the remaining ( $40 \%$ and $45 \%)$ mean score of male and female CFs were below the grand mean. This implies that there was a moderate knowledge on precautionary measure against health and environmental hazards of pesticides usage among male and female cocoa farmers in the study area. This finding agrees with [17] who put the Nigeria cocoa farmers' knowledge level on precautionary measures as favorable. Excerpts from FGD further elucidate that cocoa farmers in the study area are knowledgeable on other precautionary measures of pesticide usage, FGD affirms that 'As soon as someone finishes spraying pesticides it is good to wash your hand thoroughly with soap and lime to ensure that your hands are properly clean'. At the same time they affirm to knowledge of proper disposal of pesticide containers, 'we do burn or bury empty pesticides containers, but some farmers still leave them on their farms' Excerpt from FGD. 


\subsection{Level of Knowledge on Precautionary Measures}

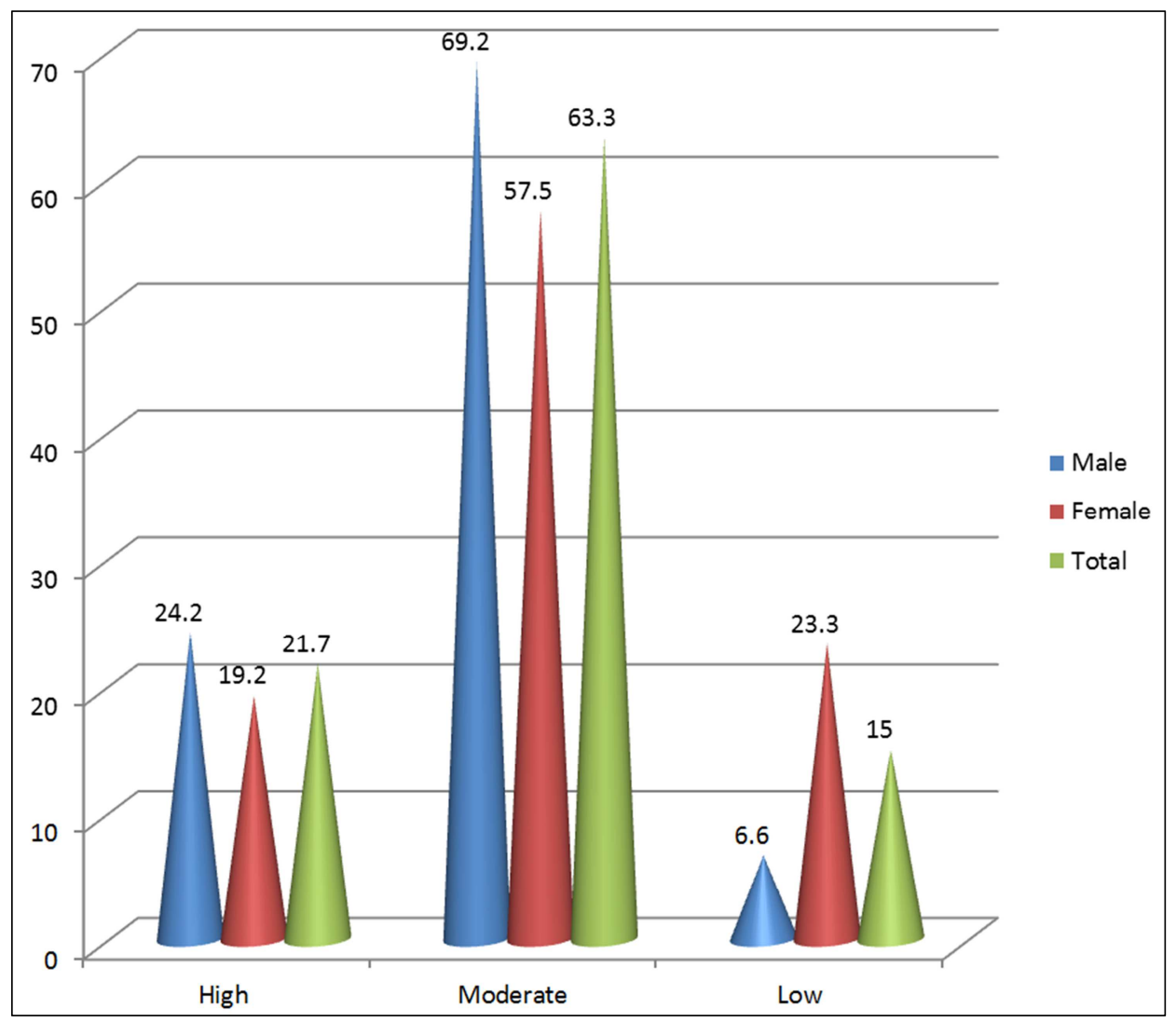

Source: Field survey, 2015.

Figure 1. Knowledge level of male and female cocoa farmers on precautionary measures

Result in Figure 1 showed the level of knowledge on precautionary measures of pesticides health and environmental hazards with majority (69.2 per cent MCF and 57.5 FCF) having moderate level of knowledge while 6.6 per cent MCF and 23.3 per cent FCF had low level of knowledge on precautionary measures. About 24 per cent and 19 per cent male and female CFs respectively had a high level of knowledge on precautionary measures. The overall result shows that majority 63.3 per cent of cocoa farmers had moderate knowledge on precautionary measures, while 15 per cent had low level of knowledge. About 22 per cent had high level of knowledge on precautionary measures. The finding indicated that male and female cocoa farmers in the study had moderate level of knowledge to prevent them from the incidence of health and environmental hazards, though male cocoa farmers had a better level of knowledge compare to their female counterparts. The variation in knowledge level among male and female cocoa farmers might be due to higher number contacts of male cocoa farmers with extension agents at the same time higher years of farming experience of male cocoa farmers. This study also find out that despite that male and female cocoa farmers are knowledgeable about the precautionary measures of health and environmental hazards they seldom practice it, which in turn contributes to the incidence of the hazards.
3.4. Correlation Analyses of the Relationship between Personal and Socio-Economic Characteristics of Male and Female Cocoa Farmers and Their Knowledge on Precautionary Measures against Pesticide Hazards

Result in table 3 showed the correlation coefficient which established the relationship between male and female cocoa farmers' personal and socio-economic characteristics and their knowledge on precautionary measures of pesticides hazards. At $\mathrm{P} \leq 0.05$ years of formal education $(\mathrm{r}=0.218)$ shows a positive significant relationship with MCF knowledge, while household size $(r=0.218)$ shows a positive significant relationship with FCF knowledge. On the other hand at $\mathrm{P} \leq 0.01$ level of significance, cocoa farming experience $(\mathrm{r}=0.300, \mathrm{r}=0.378)$ shows a positive significant relationship with male and female cocoa farmers knowledge respectively. This implies that as farmers experience increases their knowledge also increases. The experience they gathered over time provides them with knowledge to combat the incidence of health and environmental hazards. More so, at $\mathrm{P} \leq 0.01$ level of significance size of cocoa farm $(\mathrm{r}=0.292, \mathrm{r}=0.274)$ had a positive significant relationship with male and female cocoa farmers knowledge on precautionary measures. At $\mathrm{P} \leq 0.01$ income from cocoa 
$(\mathrm{r}=0.418, \mathrm{r}=0.565)$ had a positive significant relationship with male and female cocoa farmers knowledge on

precautionary measures of pesticide usage.

Table 3. Results of correlation analyses of the relationship between personal and socio-economic characteristics of male and female cocoa farmers and their knowledge on precautionary measures against pesticide hazards

\begin{tabular}{lllllll}
\hline Variables & r-value & (MALE) p-value & Decision & r-value & (FEMALE) p-value & Decision \\
\hline Age & -0.130 & 0.157 & $\mathrm{NS}$ & $0.456^{* *}$ & 0.000 & $\mathrm{~S}$ \\
Years of formal education & $0.218 *$ & 0.017 & $\mathrm{~S}$ & 0.110 & 0.230 & $\mathrm{NS}$ \\
Household size & -0.085 & 0.357 & $\mathrm{NS}$ & $0.218^{*}$ & 0.017 & $\mathrm{~S}$ \\
Cocoa farming experience & $0.300^{* *}$ & 0.001 & $\mathrm{~S}$ & $0.378^{* *}$ & 0.000 & $\mathrm{~S}$ \\
Size of cocoa farm & $0.292^{* *}$ & 0.001 & $\mathrm{~S}$ & $0.274^{* *}$ & 0.002 & $\mathrm{~S}$ \\
Income from cocoa & $0.418^{* *}$ & 0.000 & $\mathrm{~S}$ & $0.565^{* *}$ & 0.000 & $\mathrm{~S}$ \\
\hline
\end{tabular}

** Significant at $\mathrm{P} \leq 0.01$.

*Significant at $\mathrm{P} \leq 0.05$.

Source: Field survey, 2015.

\subsection{Analysis of Variance (ANOVA) Showing the Differences between Male and Female Knowledge Level on Precautionary Measures}

Result on table 4 shows that knowledge level on precautionary measures had a significant difference between male and female cocoa farmers with $(\mathrm{F}=24.962 ; \mathrm{P} \leq 0.01)$. Farmers' knowledge level in precautionary measures can be influenced by many socio-economic variables such as contact with extension agents, cocoa farming experience, and level of education. Earlier findings show that male cocoa farmers had better contact with extension agents as compare to their female counterpart and at the same had higher years of cocoa farming experience compare to their female counterparts. These variables could influence the variation in the level of knowledge of male and female cocoa farmers on the necessary precautionary measures to be taken to avert the incidence of health and environmental hazards. Excerpt from FGD affirms that majority of cocoa farmers had moderate knowledge in pesticide usage precautionary measures but they seldom follow it, the outcome of the session posited that 'most cocoa farmers, we can say have fair knowledge on how to prevent pesticides hazards, but hardly do they follow it when spraying pesticide' Excerpt from FGD.

Table 4. Summary of analysis of variance (ANOVA) showing the differences between male and female cocoa farmers knowledge on precautionary measures.

\begin{tabular}{lllllll}
\hline & SS & DF & MS & F & Sig \\
\hline Knowledge & Between groups & 2870.417 & 1 & 2870.417 & 24.962 \\
level & Within groups & 27367.433 & 238 & 114.989 & $0.000 * *$ \\
& Total & 30237.850 & 239 & & \\
\hline
\end{tabular}

**=significant at 0.01 level of significance.

$\mathrm{SS}=$ Sum of Squares, DF=Degree of Freedom, MS= Mean Square.

Source: Field survey, 2015.

\section{Conclusion}

The outcome of this study gave awareness on the Level of knowledge on various precautionary measures of pesticides usage among male and female cocoa farmers. The level of knowledge was found to be moderate among male and female cocoa farmers, though male cocoa farmers had better knowledge than their female counterpart. Cocoa farmers have varying level of knowledge on precautionary measures regardless of their sex. Despite this knowledge farmers do hardly follow these measures. Cocoa farming experience, size of cocoa farm and income from sales of cocoa positively influence the knowledge of male and female cocoa farmers on precautionary measures. There is a variation in the level of knowledge on precautionary measure among male and female cocoa farmers. It was concluded that male cocoa farmers had higher level of knowledge compare to female cocoa famers.

\section{Recommendations}

The following recommendations were made from the conclusions drawn from this study to increase and sustain the knowledge of male and female cocoa farmers on precautionary measures of pesticides usage;

a. There should be continuous and regular training by government and non-governmental organization for male and female cocoa as regards precautionary measures to be taken on pesticides usage to increase their knowledge base on pesticides hazards.

b. Even though some farmers had contact with extension agents, but improvement can still be made in the number of contacts the farmers had with extension agents and visit those who never had contacts to improve the flow of information and access to knowledge on precautionary measures of pesticides usage.

c. Farmers who are not member of farmer business school 
for cocoa production should be encouraged to join to enhance their knowledge base in cocoa production and precautionary measures of pesticide usage.

\section{References}

[1] Deji O. F. (2011): Gender and Rural Development. Berlin Series on Society, Economy and Politics in Developing Countries 106. ISBN 978-3-643-90103-3 Pp 21.

[2] Mohammed, B. T. and Abdulquadri, A. F. (2012): Comparative analysis of gender involvement in agricultural production in Nigeria. Journal of Development and Agricultural Economics 4 (8): 240-244.

[3] Ogunniyi, L. T. Ajao, O. A. and Adeleke, O. A. (2012): Gender Comparison in Production and Productivity of Cocoa Farmers in Ile Oluji Local Government Area of Ondo State, Nigeria Global Journal of Science Frontier Research Agriculture \& Biology Volume 12 (5): 1.

[4] Annon (2006): National Gender Policy; Federal Ministry of Women Affairs and Social Development printed by Amana printing limited Kaduna. Pp 7-14.

[5] Ajakaye, D. O. (1977): An overview of the non-oil sector of the Nigeria economy. Central Bank of Nigeria Economic and Financial Review, 35 (4): $14-25$.

[6] Famuyiwa, B. S. Torimiro, D. O. and Adesoji, S. A. (2013): Determination of Cocoa Farmers' Knowledge on Environmental Hazards Associated with Cocoa Farming Operations in Nigeria, International Journal of Knowledge, Innovation and Entrepreneurship 1 (1-2): 58-70.

[7] Cocoa Association of Nigeria (CAN) (2014): http://www.thisdaylive.com/articles/why-cote-d-ivoire-ghanalead-nigeria-in cocoa-production-by-can/172858/.

[8] Fasina, A. B., Badaru, K. and Aikpokpodion P. O. (2001): Development of the Nigerian cocoa industry: current issues and challenges for research and production. Proc. 13 Int. Cocoa Res. Conf. 2001, 7 (4): 1367 - 1373. 215 African Scientist.

[9] Ndubuaku, T. C. N. Ojelade, K. T. M. Asogwa, E. U. and Anikwe, J. C. (2003): Reports and recommendations on the evaluation of Pulmic System PM 120 Knapsack sprayer for protection of cocoa farms in Nigeria. Tech. Rep. CRIN, Ibadan, Nigeria, $5 \mathrm{pp}$.

[10] Asogwa, E. U. and Dongo, L. N. (2009): Problems associated with pesticide usage and application in Nigerian cocoa production: A review; African Journal of Agricultural Research 4 (8): 675-683.

[11] Mohit, J. (2008) Nigerian farmers want government to buy off banned pesticides Submitted on Wed, 07/23/2008 - 14: 35 . http://www.topnews.in/ NCDC (2008) A handbook of the 4th National Cocoa day held in Akure, Ondo State, Nigeria. Published by National Cocoa Development Committee. NCDC.

[12] Siddaramaiah, B. S. and Srinivas, B. V. (2010): Environmental Hazard in Cotton Farming Indian Perspective. www.conference.ifas.ufl.edu/papers./b1.doc.

[13] Sosan M. B. and Akingbohungbe A. E. (2009) Occupational Insecticide Exposure and Perception of Safety Measures among Cacao Farmers in South-western Nigeria Archives of Environmental \& Occupational Health, 64 (3).

[14] Lawal, B. O. Torimiro, D. O. Banjo, A. D. and. Joda, A. O. (2005): Operational Habits and Health Hazards Associated with Pesticide Usage by Cocoa Farmers in Nigeria: Lessons for Extension Work. Journal of Human Ecology. 17 (3): 191195.

[15] Asogwa, E. U. (2006): Preview of rational pesticide use protocols. Extracts from round table discussions at the NCDCsponsored farmers field school master trainers and supervisors training workshop. CRIN Ibadan, June 5-16, 2006. p. 12.

[16] Asogwa E. U. (2008): Crop protection practices for cashew and cocoa production in Nigeria. Paper presented at the National Training Workshop for Farmers Development Union (FADU) Officials on Cocoa and Cashew Production in Nigeria. Ibadan, May 8-9, 2008. 43slides.

[17] Ogunjimi, S. I. and Farinde, A. J. (2012): Farmers' Knowledge Level of Precautionary Measures in AgroChemicals Usage on Cocoa Production in Osun and Edo States, Nigeria. International Journal of Agriculture and Forestry. 2 (4): 186-194.

[18] Nigeria population commission (NPC) (2006): Population census of National Republic of Nigeria: http://www.population.gov.ng/index.php/ekiti-state.

[19] Enete, A. A. and Amusa, T. A. 2010: Determinants of Women's Contribution to Farming Decisions in Cocoa Based Agroforestry Households of Ekiti State, Nigeria "Field Actions Science Reports. " 4 (October 2012): 0-6.

[20] Ekong. E. E. (2003): Introduction to Rural Sociology; Dove educational publisher ISBN 978-36932-0-4.

[21] Yusuf O. J. (2013). Assessment of Farm Waste Utilization among Rural Dwellers in Osun State, Nigeria. An Unpublished $\mathrm{Ph}$. D. Thesis, Department of Agricultural Extension and Rural Development, Obafemi Awolowo University, Ile Ife.

[22] Owolabi, K. E, and J. O. Okunlola. 2015. "Farmers , Utilization of Indigenous Knowledge Techniques for the Control of Cocoa Pests and Diseases in Ekiti State, Nigeria." 4 (3): $247-58$. 